\title{
11
}

II. On Central-African Plants collected by Major Serpa Pinto. By Prof. Count Ficalho (Lisbon) and W. P. HIERN, M.A., F.L.S.

(Plates III.-VI.)

Read June 16th, 1881.

THE specimens herein discussed were collected by Major Serpa Pinto in the month of August of the year 1878, along the upper course of the river Ninda, an affluent of the Zambesi, on the west side of the high plateau. As regards the climate of this locality, the temperature is described as variable, the weather as very dry during seven or eight months of the year, and very wet during two or three months. The nature of the soil is metamorphic argillaceous schist; the latitude is $14^{\circ} 46^{\prime}$ south, the longitude $20^{\circ} 56^{\prime}$ east of Greenwich ; the elevation is 1143 metres above the ocean.

The readings of the thermometer at 6 o'clock on the mornings of August 11, 12, and 13 , in the year 1878 , were respectively $43 \frac{1}{2}^{\circ}, 41^{\circ}$, and $40^{\circ} \mathrm{F}$. During the same days the wind blew strongly from the east, and the sky was clear.

In consequence of the extreme smallness of the quantity of paper in the possession of Major Serpa Pinto, all he did with regard to botanical collections was to convey a few plants from this particular point of his journey. This part of Africa is fertile and salubrious, though destitute of population; and it was the first stage of the journey in which elephants were met with. He speaks of it as follows ('How I crossed Africa,' vol. i. p. 357, English edition, 1881) :- "On:the following day [10th August 1878] we penetrated into an extensive thorny forest, through which we had literally to cut our road. After a fatiguing march of five hours, the most difficult and painful I had yet had in the country, we pitched our camp at the source of the river Ninda, having left a great part of our wearing apparel on the brambles by the wayside. ... I had then at length reached the birthplace of that [p. 358] Ninda which was so renowned for the ferocity of the denizens of its banks. The lions which favoured it had not yet succeeded in devouring me; but I could not help thinking [that] if they wished to do so they must make haste about it, or they would find only the miserable remnants left by thousands of insects who considered me fair prey.... [p. 361] The river Ninda runs through a plain slightly rising to the eastward, and which I was assured extends southward all the way to the junction of the Cuando and Zambesi. Up to the point where I was encamped the forest descended thickly to the very brink of the river; but from that spot onwards there are merely groups of trees, scattered here and there over the enormous plain."

This part of the world is included in the eighth botanical region of Grisebach ("Die Vegetation der Erde,' 1872), which he designates Tropical Africa and Natal; and it would properly be considered to belong to the south-central district of Tropical Africa, 
in the sense used by Professor Oliver in his 'Flora of Tropical Africa.' It is, however, not very far from the northern boundary of the ninth botanical region of Grisebach, which he calls the Kalahari region. No collections from this locality have been previously made and forwarded to Europe to enrich our herbaria.

The present little collection consists of 72 numbers, with scarcely any duplicates, comprising 65 species, 60 of which are taken up in the following enumeration, and are referred to 39 genera ; 5 of the numbers are too imperfect for determination, and cannot with certainty be even assigned to their natural orders, except one, which is a grass in very young flower-bud.

The collection is too small to enable us fairly to judge of the proportional numbers of species in this flora belonging to the various primary divisions of the vegetable kingdom, or even to the principal natural orders.

Out of the 60 species in 39 genera detailed in the enumeration, 59 species belong to Phanerogamia and 1 only to Cryptogamia ; 24 species in 21 genera belong to Dicotyledones, and 35 species in 17 genera to Monocotyledones; in Dicotyledones 3 species in as many genera belong to Thalamifloræ, 9 species in 6 genera to Calycifloræ, 11 species in as many genera to Gamopetalæ, and 1 species to Monochlamydeæ: all the species in the class Monocotyledones belong to the series Glumiferæ.

The Gramineæ of the enumeration contain 25 species in 12 genera; the Cyperaceæ 10 species in 5 genera, the Leguminosæ (the sole representatives of the series Calycifloræ in the enumeration) contain 9 species in 6 genera ; the Compositæ, 4 species in as many genera; the Convolvulaceæ and Acanthaceæ contain 2 species each in as many genera; and of the remaining natural orders ,namely Polygaleæ, Caryophylleæ, Tiliaceæ, Rubiaceæ, Apocynaceæ, Verbenaceæ, Illecebraceæ, and Filices, each contains one species.

The numerical preponderance of Monocotyledons over Dicotyledons is fully accounted for by the large proportion of grasses and sedges; and this depended, in all probability, on the comparative ease with which the generality of such plants can be gathered, dried, and conveyed, requiring but little paper for their preservation, taking up a small space, and adding no considerable weight to a traveller's burden. In like manner is to be explained the absence of fleshy or large-foliage plants and of woody or bulky specimens.

Thus there is no specimen in the collection of the "Oúco," a grand tree, which Major Serpa Pinto, on page 361 of the first volume of his book of travels, with reference to the 14th day of August 1878, states is so abundant along the right bank of the river Ninda, and so plentiful in its blossom that for hours and hours the wayfarer is living in an atmosphere of almost overpowering perfume.

This same tree had been found previously, on the 25 th day of July 1878, on the right bank of the river Cuchibi, about latitude $14^{\circ} 3^{\prime}$ south, and longitude $20^{\circ} 8^{\prime}$ east of Greenwich. An illustration of the plant is given on page 305 of the same volume, figure 66. With regard to it we read, on pages 304-306, as follows :- "While traversing the forest I became conscious of a most delicious and delicate odour, which I found to emanate from the flower of a tree that grew abundantly about me. There is not, perhaps, any known flower that has a more fragrant perfume than the blossom of the ' Oúco' (for by that name do the natives designate the plant). The configuration of the 
tree, the arrangement of its leaves, the flowers in clusters, and, above all, my ignorance of botany induced me to speak of it in my diary as an Acacia.... . This tree, whose delicious flowers many a lady in Europe would have rejoiced to possess, I never met with before reaching this particular spot, and looked for it in vain as I approached the river Ninda."

It appears, however, as before mentioned, that the tree was met with before the river Ninda was left. The figure given in the book shows a zigzag branchlet, bearing alternate abruptly pinnate and apparently stipulate leaves with from 7 to 10 pairs of mostly opposite elliptical and sessile leaflets; the flower (which is enlarged in the figure) possesses 3 stamens, which have slender filiform filaments, bearing oval or oblong versatile anthers, also a slender and filiform style, not quite as long as the filaments, with a capitate stigma at the apex. The flowers are said to form bunches 3 centimetres long by 15 millimetres in diameter; the petals are described as 2 in number and white in colour, and the ovary and stamens as brown.

Such being all the information at our disposal with regard to the "Oúco," and there being no specimen in the collection, it would be rash to speak with any confidence as to the genus to which it belongs. It may, however, be suggested that possibly it may, when better known, eventually prove to belong to the genus Cryptosepalum, Benth., of Cæsalpinieæ; and if so, it would be an undescribed species : the specific name fragrantissimum would be suitable. If this view is correct, the organs which have been termed petals are really bracteoles.

It must be borne in mind that this branch of the Portuguese expedition to the interior of South Central Africa, which was started in the year 1877, was mainly developed as a geographical exploration, and that its leader, Major Serpa Pinto, did not lay claim to botanical knowledge; moreover, from causes which have been already hinted at, and which are more circumstantially related in his book of travels, it would have been impracticable for him to bring home any considerable herbarium from the interior of the country.

On three separate occasions even this small collection fell into imminent danger of loss or total destruction. First, at Lialui, the capital city of the kingdom of the Baróze, in the Upper Zambesi, close to the 15th parallel of south latitude, on the night of September 6 th, 1878 , the camp was set on fire by the treachery of native incendiaries, and it was only with great difficulty that the trunks containing the scientific instruments, the papers, and the gunpowder were got out and saved from the general conflagration. Secondly, near the village of Catongo, on September 10th, 1878, the carriers deserted in the darkness of night, and stole nearly all the property. Thirdly, on April 19th, 1879, in transhipping in rough weather off Durban the baggage from a little harbour-steamer to the ocean-steamer, some of the baggage fell and got crushed between the two vessels; a portion of the contents went to the bottom of the sea, and was irretrievably lost.

About a score (being a third part of the number of species set out in the following enumeration) appear to be new or previously undescribed species. Of these plants two are represented in the collection by specimens too imperfect to enable us to speak with complete certainty as to their genus; three others belong to species of grasses which 
occur also in other parts of Africa, and which have previously received names in manuscript by the late General Munro (though in one of these cases the generic name has been altered in Mr. Bentham's manuscript); one more belongs to a species which had been detected in Extratropical South Africa nearly seventy years ago, and named in manuscript by the late Mr. Burchell, whose name has been herein adopted; one is referred to a new genus, determined and named in manuscript by the late Dr. Welwitsch, and is regarded as belonging to the same species as one of Dr. Welwitsch's plants from Huilla; two more are new species, previously unnamed, and considered to be identical with specimens from Extratropical South Africa; and the remaining eleven are new species not yet known to occur otherwise than in this collection. Seven of the species were known to Linnæus.

The following 4 species of the enumeration are known to occur otherwise than in this collection, but are limited to Tropical Africa and African tropical islands, their previously known distribution being herewith supplied with their names :-

Tetrapleura andongensis, Welw. Pungo Andongo (Angola).

Oldenlandia Bojeri, Hiern. Mozambique district, South-African Gold-fields, Madagascar, and Comoro Islands.

Diplorhynchus psilopus, Welw. Huilla (Angola).

Andropogon insculptus, Hochst. Nileland.

The following 15 species of the enumeration occur also in Extratropical South Africa, but, except this collection, not in Tropical Africa :-

Polygala krumanina, Burch. South Kalahari.

Triumfetta Sondersii. Transvaal and Zululand.

Indigofera heterotricha, DC. South Kalahari, Transvaal, and Zululand.

Helichrysum nudifolium, Less. Cape Colony, South Kalahari, and Natal.

Geigeria Zeyheri, Harv. 'Transvaal.

Blepharis serrulata, Transvaal.

- Kyllingia alba, Nees ab Esenb. South Kalahari and eastern regions of Cape Colony.

Fimbristylis Burchellii. South Kalahari.

Aristida barbicollis, Tr. et Rupr. Eastern districts of Cape Colony, Transvaal, Natal, and Zululand.

A. vestita, Thunb. Cape Colony.

Sporobolus leptostachys. Transvaal.

Eragrostis gummiflua, Nees ab Esenb. Southern and eastern districts of Cape Colony.

E. Lappula, Nees ab Esenb. South Kalahari, Natal, and Zululand.

E. obtusa, Munro. Cape Colony and Transvaal.

Elionurus argenteus, Nees ab Esenb. Eastern districts of Cape Colony.

The following 11 species of the enumeration are found both in Tropical Africa and in Extratropical South Africa, but are not known to occur beyond the limits of Africa and African islands :-

Tephrosia longipes, Meisn. Transvaal, Natal, Delagoa Bay, and Karagué.

Eriosema polystachium, E. Mey. Kaffraria, Natal, Transvaal, Upper Guinea, Nileland, Lower Guinea, and Mozambique district.

Dicoma anomala, Sond. Transvaal, Natal, South-African Gold-fields, and Karagué.

Lantana salvifolia, Jacq. Southern and eastern districts of Cape Colony, South Kalahari, Natal, Transvaal, Angola, and South Centrat Tropical Africa. 
Cyperus margaritaceus, Vahl. South Kalahari, Transvaal, South-African Gold-fields, Uppcr Guinea, and Damaraland.

Panicum gossypinum, A. Rich. South Kalahari, Natal, and Abyssinia.

$P$. nigropedatum, Munro. South Kalahari and South-African Gold-fields.

$P$. insigne, Steud. South Africa and Abyssinia.

Schmidtia quinqueseta, Benth. South Kalahari, Transvaal, Upper Guinea, Nileland, and Mozambique district of Tropical Africa.

Eragrostis elata, Munro. South Kalahari, Orange Free State, Transvaal, Delagoa Bay, and SouthAfrican Diamond-fields, also Mozambique district of Tropical Africa and Angola.

Andropogon eucomus, Nees ab Esenb. South-western districts of Cape Colony, Natal, Mozambique district of Tropical Africa, Upper Nileland, and Lower Guinea.

For the purpose of these lists, the South-African Gold-fields, where no precise locality is given, are considered to belong to the south-central district of Tropical Africa. Moreover the Tropical Africa spoken of means that part of Africa contained between the tropics of Cancer and Capricorn; and in this sense it is taken in Professor Oliver's 'Flora of Tropical Africa ;' and it is not used to denote the botanical region of "Tropical Africa and Natal " according to Grisebach, which includes part of the Transvaal, also Zululand and Natal, in addition to the part of Africa which is tropical in a geographical sense, with the omission, however, of a portion which belongs to the Kalahari region.

On taking the general indications about the geographical affinities of the flora of this point of the upper Zambesi system which the first two lists above given supply, we may observe that, whereas only 4 species of the enumeration are peculiar to Tropical Africa (in the geographical sense), the various principal districts of that large area being mostly represented, with a slight preponderance in favour of Angola, so many as 15 species occur in Extratropical South Africa, and not again in Tropical Africa; of these 15 species 7 occhr in the Transvaal, 7 in Cape Colony, 6 in South Kalahari, 4 in Zululand, and 3 in Nat. Thus, such a limited view would make it appear that the flora of the upper course of the river Ninda is allied to that of Extratropical South Africa rather than to that of the greater part of Tropical Africa; and this alliance is illustrated in the collection by the larger representation of Compositæ as compared with Rubiaccæ. On the other hand the high proportional number of Leguminosæ over that of the former of the other two natural orders points to a peculiarity of the flora of Tropical $A$ frica as contrasted with that of Extratropical South Africa.

From the third list it is found that of the species which are limited to Africa, but which occur both in Tropical Africa and in Extratropical South Africa, 7 species of the enumeration occur in the Transvaal, 7 in Nileland, 6 in South Kalahari, 6 in Natal, 4 in Lower Guinea, 4 in Cape Colony, 4 in South Central Tropical Africa otherwise than in this collection, 4 in the Mozambique district of Tropical Africa, 3 in Upper Guinea, 2 at Delagoa Bay, 1 in Damaraland, 1 in the Orange Free State, and 1 in the SouthAfrican Diamond-fields.

Three species of the enumeration occur both in Africa and Asia, but not in Australia, America, or Europe; 3 species occur both in Africa, Asia, and Australia, but not in America or Europe; 1 species occurs in Africa, Asia, and America, but not in Australia or Europe; 5 species occur both in Africa, Asia, Australia, and America, but not in Europe; 3 species occur both in Africa, Asia, Australia, America, and Europe; 1 species 
occurs in Africa and America only; and 1 species occurs in Africa, Asia, and Europe, but neither in Australia nor America.

The majority of the genera represented in the enumeration are well-known types, with a wide geographical distribution both in the eastern and western hemispheres, and with numerous species; of the genera previously known only 4 are peculiar to Africa, of which one is exclusively tropical, one both tropical and extratropical southwards, and two were only known previously to be south extratropical genera. One new genus is named and fully described below.

The five numbers which are too imperfect for determination are as follows :-

A barren leafy shoot, with sessile leaves, having pellucid veinlets, rather suggestive of a simple-leaved species of Rhus: Serpa Pinto, no. 30.

A branch without either flowers or fruit, but with simple alternate oval petiolate stipulate leaves $1 \frac{1}{2}-2$ inches long, having parallel erecto-patent lateral veins; the plant is said to produce an edible fruit; nativename "Ulama;" from the high plateau : Serpa Pinto, no. 11.

A barren branch, with crowded narrow leaves: Serpa Pinto, no. 26.

A portion only of a fruit, from the high plateau; native name "Sanarubia" : Serpa Pinto, no. 31.

A grass, the upper part of a plant in very young flower-bud : Serpa Pinto, no. 38.

Enumeration of Plants collected.

POLYGALE无.

1. Polygala krumanina, Burchell, MS. in Herb. Kew. $P$. perennis suffruticosa ramosissima procumbens trium vel quatuor pollicum alta, ramis teretibus fibratis, ramulis foliosis pubcrulis pilis brevibus crispulis, foliis alternis lineari-spathulatis, $\frac{1}{3}-\frac{1}{2}\left(-\frac{2}{3}\right)$ pollicaribus subcoriaceis puberulis vel glabratis uninerviis apice mucronulatis vel obtusis basi angustatis sessilibus margine incrassato-revolutis, floribus lateralibus solitariis (vel in cymis brevibus paucifloris dispositis) bracteatis foliis subæquantibus, pedicellis brevibus, bracteis caducis, sepalis integris interioribus obovatis apiculatis albido-viridibus demum albescentibus carina paulum brevioribus, sepalis interioribus inter se liberis, petalis lateralibus $\frac{2}{3}$ long. carinæ, carina $\frac{1}{5}$-pollicari dorso cristata, crista conspicua multifido-lobata, staminum filamentis superne liberis, capsula ovali $\frac{1}{5}$-pollicari subglabra sepalis interioribus sublatiore apice emarginata sinu ovato lobis ovatis, seminibus pilosis $\frac{1}{8}$-pollicaribus, caruncula $\frac{1}{20}$-pollicari 3 appendiculata.

This species has been previously obtained in the southern part of the Kalahari region of Extratropical South Africa, in the year 1812, by Burchell, nos. 2425, 2474, 2599, as under; in Burchell's specimens the leaves range up to two thirds of an inch in length.

Burchell, no. 2425 : near the ruins of the Bachapin town on the Krúman, November 16, 1812. A specimen of this number in the Kew Herbarium is marked by Burchell as having been seen by the eldest DeCandolle; the plant, however, does not appear to have been taken up in DeCandolle's 'Prodromus,' nor in the 'Flora Capensis' of Harvey and Sonder, of which the first volume (the one containing the genus Polygala) was published 
in the year 1860, although in the preface to the 'Flora Capensis' the thanks of the authors are said to be due to Burchell for the verification of several of the species of Polygala first described from his specimens.

Burchell, no. 2474: in a walk to the Great Klibbolikhónni Spring (or source of the river Krúman), November 25, 1812.

Burchell, no. 2599: at the Kosi Fountain, on the morning of December 25, 1812. It was at this station that Burchell at the same time obtained specimens of our Fimbristylis Burchellii, described below, page 28. The species belongs to the group containing the East-Indian $P$. rosmarinifolia, Wight et Arn.

Serpa Pinto, no. 29.

\section{CARYOPHYLLE $\nexists$.}

2. Diantiuus Serpe, sp. n. (Plate III. A. figs. 1, 2.) D. subglaber, caulibus bipedalibus vel ultra erectis vel strictim ascendentibus subteretibus ut videtur in specimine nostro unico indivisis unifloris basim versus foliosis, foliis lineari-lanceolatis acutis vel subacutis rigirle coriaceis 7-3-nerviis margine scabridulis 2-3 pollices longis superioribus minoribus per paria remotis supremis bracteæformibus $\frac{2}{5}$-pollicaribus, floribus solitariis, bracteis 4 decussatim imbricatis ovatis cuspidatis pari exteriore semipollicari pari interiore $\frac{2}{3}$ poll. longo, calyce rigido tubuloso subcartilagineo striato sesquipollicari tubo fere pollicem longo 1 poll. lato lobis ovato-lanceolatis acutis erectis, petalis spathulatis lamina obovata acuta inciso-fimbriata subpollicari ut videtur albida ungue calycem aequante, ovarjo $\frac{2}{5}$ poll. longo.

Our specimen consists only of a flowering stem or branch; it bears some resemblance to Dianthus prostratus, Jacq. ; but it differs from it by the more acute form of the general outline of the blade of the petals, and by the more deeply cut margins of the same.

The principal figure in Plate III. A. represents the natural size of the specimen; the dissected flower is enlarged to about two diameters.

Serpa Pinto, no. 24.

\section{TILIACE $\mathrm{E}$.}

3. Trilmfetta Sonderin, nobis. T. trichocarpa, Sond. in Linnaea, xxiii. p. 19 (1850); Harv. in Harv. et Sond. Fl. Cap. i. p. 228 (1860); non Hochst. (1847).

Our specinens possess flowers and fruits, and quite agree with Sonder's species, which has also been obtained from the Transvaal and Zululand. In a flower opened for examination the stamens were 18 in number. Hochstetter's T. trichocarpa, from Abyssinia, is quite distinct.

Serpa Pinto, no. 27.

\section{LEGUMINOS}

4. Crotalaria erisemordes, sp. n. C. suffruticosa inermis dense ramosa villosa pilis albidis ut videtur nana, ramis teretibus demum glabratis ramulis tenuibus hirtis foliosis, foliis digitatim trifoliolatis petiolatis hirtis, foliolis obovato-ellipticis ciliatis utrinque acutatis supra glabris infra villosis sæpe (in sicco) conduplicatis integer- 
rimis subsessilibus lateralibus fere semipollicaribus centrali ceteris leviter majore, petiolo hirto tenui $\frac{1}{5}-\frac{1}{3}$-pollicari, stipulis foliaceis integerrimis $\frac{1}{4}-\frac{1}{3}$-pollicaribus ciliatis, floribus axillaribus vel lateralibus solitariis vel geminis brevissime pedunculatis cernuis $\frac{3}{8}-\frac{1}{3}$-pollicaribus, calyce profunde fisso extus hirto corollam circiter æquante lobis lanceolatis acutis inter se subæqualibus, staminibus 10 monadelphis tubo superne partito, ovario compresso oblique obovato $\frac{1}{5}$-pollicari villoso multiovulato, stylo basi supra ovarium abrupte incurvo glabro, legumine subcompresso villoso oblique ovali $\frac{3}{8}$-pollicari, funiculis filiformibus, seminibus circiter 14-18.

The species to which our plant has nearest affinity appears to be C. Forbesii, Baker in Oliv. Fl. Trop. Afr. ii. p. 18 (1871).

Serpa Pinto, no. 3.

5. Indigofera heterotricha, DC. Prodr. ii. p. 227, n. 61 (1825); Harv. in Harv. et Sond. Fl. Cap. ii. p. 189 (1862).

This species occurs also in Fxtratropical South Africa, having been found in the year 1812 in the southern part of the Kalahari region by Burchell as under, at Magalisberg in the Transvaal by Burke and Zeyher in the year 1841, and in Zululand by Miss Owen.

Burchell, no. 2526, on the road from Little Klibbolikhonni and the (Great) Kosi Fountain, on the morning of December 20, 1812; here Burchell also collected Panicum gossypinum, A. Rich., given in the enumeration below, page 29.

Burchell, no. 2635, ; at the (Kora) Klip Fontein, December 29 and 30, 1812 ; caules hispidi fruticosi erecti, folia pinnata 5-juga, racemi fructiferi longissimi axillares (Burch. MS.). On this number of Burchell DeCandolle founded the species.

In our specimens, which are rigidly herbaceous rather than shrubby, the leaflets vary from 7 to 11 (rarely 6 ) in number; the calyx measures about $\frac{1}{8}$ inch, and the membranous nearly glabrous corolla measures about $\frac{1}{3}$ inch in length.

Serpa Pinto, no. 28.

6. Indigofera doDECAPHYLla, sp. n. I. cinereo-canescens inermis primum subaureonitescens palmaris vel ultra basi frutescens, caulibus hispido-pubescentibus leviter sinuosis subangularibus, foliis pinnatis strigoso-hispidis subsessilibus vel brevipetiolatis $\frac{3}{4}-1 \frac{1}{4}$-pollicaribus, stipulis subulatis hispido-pubescentibus $\frac{1}{8}-\frac{1}{7}$-pollicaribus, petiolo cum rhachi hispido-pubescente, foliolis 7-13 sæpius 11-12 alternis vel suboppositis cum terminali brevi-petiolulato ovalibus vel obovatis apice obtusis mucronatis basi plus minusve angustatis brevissime petiolulatis supra hispido-strigosis infra appresse pilosis $\frac{1}{3}-\frac{2}{5}$-pollicaribus, racemis axillaribus sub floribus folia æquantibus sub fructibus sesqui vel bis excedentibus densifloris, pedunculo semipollicari, calyce $\frac{1}{6}$-pollicari piloso-pubescente profunde lobato lobis subulatis inter se subæqualibus, corolla calycem parum excedente, staminibus 10 diadelphis antheris parvis apiculatis, ovario pubescente, stylo glabro, legumine lineari-oblongo obtuse tetragono pubescente pilis crispulis albidis semipollicari, seminibus pluribus. 
The closest affinity of this species appears to be with $I$. daleoides, Benth., a plant belonging to the Transvaal, Zululand, and Benguella.

Serpa Pinto, no. 7.

7. Indigofera splendens, sp. n. (Plate III. B. figs. 3-12.) I. inermis, ramis apice canescentibus breviter pubescentibus subherbaceis plus minusve flexuosis, foliis pinnatis sæpius imparipinnatis erecto-patentibus internodia ter vel quater excedentibus petiolo $\frac{1}{5}-\frac{1}{3}$-pollicari incluso $1 \frac{1}{2}-3$ pollices longis, stipulis lanceolato-subulatis petiolum subæquantibus, foliolis 6-11-jugis oppositis ovalibus utrinque obtusis sæpe mucronulatis integerrimis breviter petiolulatis $\frac{3}{10}-\frac{2}{5}$ poll. longis supra glabratis vel subglabris infra appresse canescenti-pubescentibus, stipellis brevibus glandulæformibus rubentibus glabris, racemis spicæformibus axillaribus et quasi-terminalibus breviter pedunculatis densifloris rectis rigidis breviter pubescentibus pedunculo $\frac{1}{2}-\frac{3}{4}$ pollicari incluso $1 \frac{1}{2}-3 \frac{1}{2}$ pollices longis, bracteolis caducis, floribus $\frac{5}{8}-\frac{2}{3}$-poll. brevissime pedicellatis, calyce profunde lobato extra pubescente intra glabro lobis lanceolatis $\frac{1}{8}-\frac{1}{6}$-poll., corolla pro genere magna splendente, staminibus diadelphis antheris uniformibus parvis apiculatis, legumine (immaturo) oblongo recto appresse pubescente $\frac{1}{4}$-pollicari.

This species is allied to Indigofera sutherlandioides, Welw., and to I. fulgens, Baker ; it differs from the former by its large flowers, and from the latter by its dense racemes and smaller foliagre.

The principal figure in Plate III. B represents the natural size of a flowering branch; the portion of the leaf, the detached flower, and the separate petals are enlarged to two diameters or rather more; the androcium, shown with the calyx persisting, and also the detached pistil, are enlarged to about four diameters; the anther, with part of the filament, is still more enlarged; the young legume is somewhat enlarged.

Serpa Pinto, nos. 1 and 4 .

8. Tephrosta longipes, Meisn. in Hook. Lond. Journ. Bot. ii. p. 87 (1843); Harv. in Harv, et Sond. Fl. Cap. ii. p. 208 (1862); Baker in Oliv. Fl. Trop. Afr. ii. p. 120 (1871); Grant et Oliv. in Trans. Linn. Soc. Lond. xxix. p. 56 (1872).

This species occurs also in Natal, in grassy places at the base of the Tafelberg Mountains, at an elevation of 1500 feet; in the Transvaal ; at Delagoa Bay ; and in Karagué, about $2^{\circ}$ S. lat., at an elevation of 4500 feet.

Serpa Pinto, no. 2.

9. Tephrosia Purpurea, Pers. Syn. Pl. ii. p. 329 (1807); DC. Prodr. ii. p. 251, n. 12 (1825), cum syn.; Baker in Oliv. Fl. Trop. Afr. ii. p. 124(1871), cum syn.; Baker in Hook. f. Fl. Brit. Ind. ii. p. 112 (1876), cum syn. T. lineata, Schum. et Thonn. in Schum. Beskr. Guin. Pl. p. 376 (1827), et in Dansk. Vid. Selsk. Nat. iv. p. 150 (1829).

Our specimen, which is in young flower, is much more pubescent than most of the forms of this species. The type specimen of Cracca purpurea, L. Sp. Pl. edit. i. p. 752 
(1753), on which Tephrosea purpurea, Pers., is supposed to have been based, has been specially inspected in the Linnean herbarium for comparison with our specimen; the resemblance, however, is by no means close.

The species is widely distributed over the Tropics.

Serpa Pinto, no. 8.

10. Eriosema polystachivm, E. H. F. Mey. Comim. Pl. Afr. Austr. Drège, p. 130 (1835). E. polystachyum E. Mey., ex Krauss in "Flora," Jahrg. 27, 1844, p. 357 et Beitr. Fl. Cap. und Nat. p. 55 (1846); non Baker. Rhynchosia cajanoides, Guill. et Perr. in Guill. Perr. et A. Rich. Fl. Senegamb. Tent. i. p. 215 (1833). Eriosema cajanoides, Hook. f. et Benth. in Hook. Niger Fl. p. 314 (1849); Harv. in Harv. et Sond. Fl. Cap. ii. p. 261 (1862); Baker in Oliv. Fl. Trop. Afr. ii. p. 227 (1871), cum syn.

Our specimens are in flower and fruit, and quite accord with this handsome species, which occurs also in other districts of Tropical Africa, and extends to the Transvaal, Kaffraria, and Natal (among reeds near the river Umlaas).

Serpa Pinto, no. 5.

11. Badinina Serpe, sp. n. B. molliter velutina ramosa, (in sicco) fulvo-fusca, ramulis erecto-patentibus, foliis transverse ovalibus bifidis chartaceis utrinque molliter pubescentibus apice in sinu setaceo-cuspidatis basi profunde cordatis margine anguste revolutis, superioribus $1 \frac{1}{2}-2$ poll. lat., $1 \frac{1}{4}-1 \frac{1}{2}$ poll. long., lobis vel foliolis 2 oblique ovalibus rotundatis tricostatis secus folii costam $\frac{1}{2}-\frac{5}{8}$ poll. connatis, petiolo $\frac{1}{5}-\frac{1}{4}$-pollicari, stipulis lineari-lanceolatis acutis deciduis $\frac{1}{3}$-poll., floribus fere bipollicaribus, pedunculo oppositofolio solitario subpollicari apice bracteolato, pedicello solitario vel subsolitario incrassato vel compresso-dilatato 1-1 $\frac{1}{2}$-pollicari, calyce breviter pubescenti-velutino $1 \frac{1}{8}$ poll. longo, lobis apiculatis fere usque ad apicem in tubum ovoideo-oblongum connatis, petalis fere 2 pollices longis $\frac{1}{2}-\frac{2}{3}$ pollices latis ovalioblongis margine crispo-dentatis unguiculatis lamina in unguem $\frac{1}{5}$-pollicarem abrupte angustata, staminibus perfectis quinque $1-1 \frac{1}{2}$ poll. longis filamentis inter se inæqualibus sub apice pubescentibus antheris $\frac{1}{4}-\frac{3}{8}$-poll., staminibus anantheris 5 in phalangem pubescentem semipollicarem connatis, ovario $\frac{3}{4}$-pollicari in gynophoro semipollicari suffulto stylo $\frac{1}{2}$-pollicari stigmate hemispharico capitato, fructibus teste cl. Serpa Pinto edulibus.

Habitat in regione alto-plana; nomen vernaculum "Quieira."

This species appears to have its nearest affinity with $B$. macrantha, Oliv., a species from South Central Africa.

Serpa Pinto, no. 9.

12. Tetrapleura andongensis, Welw., ex Oliv. Fl. Trop. Afr. ii. p. 331 (1871); Benth. in Trans. Linn. Soc. Lond. xxx. p. 376 (1875).

Habitat in regione alto-plana ; nomen vernaculum " Mulolo."

Our specimen consists only of a leaf, but appears to accord well with this species, which was found by Welwitsch, no. 618, in the high forests at the base of the rocks of 
Pedras de Guinga, Pungo Andongo, Angola, in March 1857. Welwitsch states that the plant has the habit of an Acacia of the group of $A$. lata, Br.

Serpa Pinto, no. 6.

Another specimen, consisting only of part of a leaf, may possibly belong to the same species ; it also occurred on the high plateau ; its local name is "Chipa."

Serpa Pinto, no. 10.

\section{RUBIACE E.}

13. Oldenlandia Bojeri, Hiern in Oliv. Fl. Trop. Afr. iii. p. 53 (1877), cum syn.

Our specimens are in flower, and are small forms of the species, which occurs also in the Mozambique district of Tropical Africa, in the South-African Gold-fields, in the island of Madagascar, and in the Comoro Islands.

Serpa Pinto, no. 25.

\section{COMPOSITE.}

14. Amphidoxa fildainea, sp. n. (Plate IV. tigs. 1-10.) $A$. herbacea argenteo-canescen s semipedalis habitu spisso a basi ramosissima erecta capite globoso demum obsolete sericeo-tomentella, caudice suffruticoso, ramis ramulisque erectis vel ascendentibus apice argenteis lanato-tomentellis foliosis, foliis alternis sublinearibus obtusiusculis sessilibus subamplexicaulibus persistentibus basim versus paulum latioribus $\frac{1}{8}-\frac{1}{3}$-pollicaribus primum appressis demum patulis ramis ramulisve concoloribus crassiusculis marginibus plus minusve involutis, capitulis campanulatis $\frac{1}{8}-\frac{1}{6}-$ pollicaribus heterogamis discoideis multifloris sessilibus subsessilibusve basi pallidofuscis sublanatis apice niveis glabris 2-5nis in glomerulis terminalibus subterminalibusque aggregatis, bracteis involucri pauciserialibus imbricatis obtusis interioribus lineari-oblongis $\frac{1}{8}-\frac{1}{6}$-pollicaribus corollas excedentibus supra medium niveis glabris apice subradiantibus exterioribus ovatis brevioribus basi extra sublanatis, floribus $q \infty$ filiformibus epapposis, floribus $\stackrel{\circ}{+}$ interioribus circiter $9-11$ sterilibus (?) papposis tubulosis, antheris apice appendiculatis basi breviauriculatis minute caudato-appendiculatis, granulis pollinis globosis tuberculatis styli florum $\stackrel{0}{+}$ ramis apice truncatis inappendiculatis, achæniis ovali-oblongis subglabris minutissime papillosis, setis pappi paucis (3-5) setaceo-clavatis sursum plumoso-barbellatis, receptaculo nudo parvo.

The general appearance of the plant (in the dried state) is like that of Helichrysum declinatum, Less. It constitutes a second species of the genus to which it belongs, the first species being a Cape and Natal plant, with linear-spathulate leaves.

The principal figure in Pl. IV. represents the natural size of the whole of our specimen; the detached flower-head is enlarged to five diameters; the piece of a branchlet with two leaves is enlarged to about six diameters; the separate florets are enlarged to about thirty diameters.

Serpa Pinto, no. 14.

15. Helichrysum nudifolitm, Less. Syn. Gen. Comp. p. 299 (1832); DC. Prodr. vi. 
p. 200, n. 163 (1837) ; Harv. in Harv. et Sond. Fl. Cap. iii. p. 240 (1865). Gnaphalium nudifolium, L. Pl. Afr. Rar. n. 56 (1760) in Amoen. Acad. vi. p. 99 (1763).

Our specimen is a very good one. The type specimen in the Linnean herbarium has been specially examined for the identification of our specimen. The species has an extensive distribution throughout Cape Colony, and extends to South Kalahari and Natal. It was not previously known to occur in Tropical Africa.

Serpa Pinto, no. 16.

16. Geigeria Zeyheri, Harv. in Harv. et Sond. Fl. Cap. iii. p. 126 (1865).

In our specimen the involucral bracts are less produced into leafy tips than usual in this species, though examples like ours occur in other specimens. The species has previously been obtained from the Transvaal.

Serpa Pinto, no. 15.

17. Dicoma anomala, Sond. in Linnæa, xxiii. p. 71 (1850); Harv. in Harv. et Sond Fl. Cap. iii. p. 517 (1865); Oliv. et Hiern in Oliv. Fl. Trop. Afr. iii. p. 443 (1877), cum syn.

This species, with its varieties, occurs also in the Transvaal and Natal, in the upper part of Nileland, and in the South-African Gold-fields. Our specimens, wbich are viscidglandular, agree best with the variety a. Sonderi of Harvey.

Serpa Pinto, no. 17.

\section{APOCYNACEÆ.}

Diplorhynchus, Welw. MS., gen. nov.

Calyx 5-fidus campanulatus parvus eglandulosus, lobis ovatis obtusiusculis inter se subæqualibus basi leviter imbricatis. Corolla urceolari-infundibularis profunde 5-fida alba, tubo supra medium paulum ampliato ore subconstricto, fauce gibbis seu squamis dentiformibus adnatis applicatisve aucta, lobis ovali-oblongis patentibus demum recurvis intra laxe puberulis in astivatione dextrorsum (ab axe deorsum spectanti) convolutis. Stamina 5 inclusa glabra medio corollæ tubo inserta cum lobis corollæ alternantia, filamentis brevibus, antheris triangulari-pyramidatis apiculatis luteis a stigmate liberis apicibus conniventibus loculis basi polliniferis obtusis inappendiculatis. Discus obsoletus vel inconspicuus brevis annularis glaber. Ovarium supcrum depresso-globosum glabrum 2-loculare, carpellis 2 separabilibus biovulatis vel rarius quadriovulatis, stylo unico albido basi sæpe fisso, stigmate viridi quam stylus multo latiore cupuliformi medio intra cupulum materiam stigmatoideam rubram ovato-conicam bilobam ferente, ovulis superpositis, placentis ventralibus. Folliculi gemini a basi distincti divergentes lignosi vel crasse coriacei subcompressi ovales aperte dehiscentes. Semina inquoque folliculo 2 vel rarius 4 superposita plano-compressa peltatim affixa apice late alata.

Arbores vel frutices scandentes vel stantes, glabri, sæpe lactescentes. Folia opposita vel subopposita, sempervirentia, delicate reticulata, coriacea, lucida. Flores parvuli, fragrantes, in cymis terminalibus multifloris pyramidato- vel globoso-corymbosis dispositi. Folliculi $1 \frac{1}{2}-1 \frac{3}{4}$-pollicares.

Species adhuc cognitæ 3, Africæ tropicæ australis incolæ.

Besides the species described below, there are two other species, one from the Mozambique district (Benth. in Hook. Ic. Pl. t. 1355, ined.), the other from Angola (Welw. hb. nn. 5968, 5983, 5984). 
The affinity of this genus is with Gonioma, E. Mey., from which it differs by the different shape of the corolla with longer lobes, and by the presence of adnate teeth or gibbosities within the throat, by definite ovules and seeds, and by the opposite or subopposite not verticillate leaves.

18. Diplorhynchos Psilopts, Welw. MS. in Herb. n. 5982. (Plate V. figs. 1-9.) $D$. ramis in sicco brunneo-rubescentibus teretibus, ramulis foliosis, foliis oppositis vel rarius ultimis subsparsis suboblique ovalibus apice obtuse acuminatis retusisve busi plus minusve cuneatis petiolatis tenuiter coriaceis nitidis eleganter reticulatis 1-2 pollices longis $\frac{1}{2}-1$ poll. latis, costa venisque leviter pellucidis, petiolo $\frac{1}{3}-\frac{1}{2}$-poll. angustissime alato sæpe (in sicco) unilateraliter verso, cymis laxe ramosis semiglobosis $2-2 \frac{1}{2}$ poll. diam., pedunculo $\frac{1}{8}-\frac{2}{3}$-pollicari, pedicellis minute puberulis approximatis $\frac{1}{8}$-poll., bracteolis parvis, alabastris tylindraceis $\frac{1}{4}$-poll., floribus $\frac{1}{6}$-poll., calyce minute puberulo, corolla extus glabra, ovulis in quoque carpello 2 superpositis.

Habitat in regione alto-plana ; nomen vernaculum "Mussala Canjanga."

The description given above is taken from our specimens. According to a note made by Major Serpa Pinto the fruit is edible; but this statement does not appear to be probable, at least in the case of Welwitsch's specimens; the latter appear to belong to the same species, though in those plants the habit is more robust, the leaves range up to 3 inches in length by $1 \frac{2}{3}$ inch in width, the petioles to 1 inch in length, the inflorescence is less lax, and often of smaller diameter, the pedicels are more conspicuously puberulous and some of them are shorter, and the unopened flowers range up to $\frac{1}{3}$ inch in length; the follicles open nearly flat, are broadly oval, retuse at the apex, 2 -seeded, and measure $1 \frac{1}{2}$ inch long by $1 \frac{1}{5}$ inch wide; the pericarp is hard, and very thickly leathery, warted outside, smooth and chestnut-coloured inside; the seeds measure 1 inch long by $\frac{2}{5}$ inch wide. The following is a copy of Welwitsch's manuscript notes appended to his number 5982 :- “ Arbor parva, nunc frutex scandens, nunc arbuscula stans uno alterove ramo scandente ; folia sempervirentia coriacea lucida ; flores albi fragrantissimi ; planta lactescens. Habitat (distr. Huilla) in editioribus collinis prope Nene una cum Combretaceis, Octobr. 1859, c. fl. et fr."

Of the genus the other species obtained by Welwitsch in Angola is called by the Portuguese colonists " Jasmincira " or "Jasmin de Cazengo."

The principal figure in Plate $V$. represents the natural size of a flowering branch of Major Serpa Pinto's plant; the detached flower and flower-bud are enlarged to about four diameters; the other dissections are more considerably enlarged.

Serpa Pinto, nos. 12 and 13.

\section{CONVOLVULACEA.}

19. Ipomca angtstifolia, Jacq. Collect. ii. 367 (1788), et Ic. Pl. Rar. ii. t. 317 (17861793); non Choisy. Ipomoea filicaulis, Blume, Bijdr. Fl. Ned. Ind. p. 721 (1825); Choisy in DC. Prodr. ix. p. 353, n. 31 (1845), cum syn.; Benth. in Hook. Niger Fl. p. 466 (1849). 
This species is widely spread over Tropical Asia, Africa, and Australia; it also occurs in Extratropical South Africa.

Serpa Pinto, nos. 18, 19.

20. Evolvulus alsinoides, L. Sp. Pl. edit. ii. p. 392 (1762); Choisy in DC. Prodr. ix. p. 447, n. 40 (1845); Benth. et Muell. Fl. Austral. iv. p. 438 (1869); Grant et Oliv. in Trans. Linn. Soc. Lond. xxix. p. 117 (1875). Evolvulus linifolius, L. l. c..; Choisy, l. c. p. 449 , n. 50 .

This is a common tropical species, and subject to much variation of form. The type specimens in the Linnean herbarium have been specially inspected for comparison. Our specimen is a form with very slender stems and branches and small leaves, thus approaching the typical form of $E$. alsinoides, $L$., but with the narrowly lanceolate shape of its leaves as in $E$. linifolius, $\mathrm{L}$.

Serpa Pinto, no. 20.

\section{ACANTHACEÆ.}

21. Blepitaris serrulata, nobis.-Acanthodium serrulatum, Nees ab Esenb. in DC. Prodr. xi. p. 275, n. 8 (1847).

The species quoted above occurs in the Transvaal. The type, collected by Burke, in the Kew herbarium agrees with our specimen. The specimen of Burchell, quoted by Nees l. $c$., we do not find in the Kew herbarium; the name of Burchell was probably printed by mistake for Burke. The species does not appear to have been noted by T. Anderson, in Journ. Linn. Soc. Lond. vii. p. 34 (1863), among the South-African species of the genus.

Serpa Pinto, no. 22.

22. Crabben ovalifolia, sp. n. (Plate VI. A. figs. 1-6.) C. herbaceo-suffruticosa procumbens puberula, caulibus teretibus breviter pubescentibus ut videtur prostratis simplicibus, foliis ovalibus integris vel subrepandis puberulis rigide membranaceis, in sicco secundis crectis, apice obtusis vel obtusiusculis basi angustatis 2-3 pollices longis $\frac{2}{3}-1 \frac{1}{4}$ poll. latis, petiolo $\frac{1}{4}-\frac{2}{5}$-pollicari robusto breviter pubescente, internodiis $\frac{3}{8}-1 \frac{1}{4}$-poll., floribus fere pollicaribus capitatis sessilibus in spicis abbreviatis bracteosis subhemisphæricis axillaribus solitariis secundis erectis breviter pedunculatis congestis, bracteis lanceolatis acutis subpollicaribus calyces excedentibus herbaceis basi imbricatis involucrantibus breviter pubescentibus margine spinuloso-ciliatis ciliis albido-ciliolatis, bracteis nullis nisi flores abortivos simulantibus minoribus, calyce $\frac{2}{3}$-pollicari 5-partito hirsuto segmentis anguste lanceolatis acutis parum inter se inæqualibus, corolla ${ }_{5}^{4}$-pollicari extra atque intra ad faucem et staminum insertionem puberula tubo $\frac{5}{8}$-pollicari cylindraceo-infundibuliformi ad faucem paulum oblique ampliato limbo 5-lobo oblique patulo lobis rotundatis $\frac{1}{3}$ poll. longis in æstivatione imbricatis, staminibus 4 didynamis inclusis infra medium tubum insertis filamentis glabris per paria inæquilongis longioribus $\frac{1}{8}$-pollicáribus brevioribus $\frac{1}{1}$-pollicaribus antheris ciliolatis bilocularibus muticis, disco brevi oblique cupulari 
glabro, pistillo semipollicari glabro incluso stylo gracili stigmate oblique dilatato, ovario biloculari loculis 2-3-ovulatis.

Nearly related to the Natal species, Crabbea hirsuta, Harv., from which it differs by broader leaves and by the more conspicuous hoary hairs on the bracts.

The principal figure in Pl. VI. A. represents the natural size of the specimen; the detached flower is enlarged to two diameters; and the other more detailed dissections are more considerably enlarged.

Serpa Pinto, no. 21.

\section{VERBENACE无.}

23. Lantana salvifolia, Jacq. Hort. Schœnbr. iii. p. 18, t. 285 (1798). L. salviafolia, Schauer in DC. Prodr. xi. p. 605, n. 41 (1847), cum syn.

This species is widely distributed over both Tropical and Extratropical South Africa. Serpa Pinto, no. 23.

\section{ILLECEBRACE里.}

24. Genus vix adhuc descriptum.

Flores hermaphroditi in capitulum terminale solitarium bracteolatum aggregati. Perianthium inferum siccum 5-phyllum; segmenta erecta lineari-oblonga vel linearia imbricata quincuncialia apiculata chartacea margine scariosa apice excepto lanata carinata trinervia, exteriora latiora sublongiora lanatiora. Corolla nulla. Stamina 5 subhypogyna inter se subæqualia glabra perianthio subbreviora ; filamenta complanata tenuia basim versus dilatata ad basim connata ; antheræ biloculatæ oblongæ. Ovarium superum ovoideum ventricosum basi excepta lanatum 1-loculatum apice distylum; stylus alter filiformis glaber perianthio subæquilongus apice minute capitatus stigmatosus, alter abbreviatus externe lanatus corniculatus abortivus. Ovulum pendulum e funiculo longo apice curvo a basi ovarii ascendente.

Herba facie graminea, foliis supremis oppositis anguste linearibus sessilibus valde acutis pollicaribus.

The affinity of the genus appears to be with Cometes, L., which consists of two species, one belonging to North-eastern Africa and Tropical Arabia, the other to Persia. We refrain from giving a new name till more of the plant is known.

Our specimen consists of the upper portion of the plant, 4 inches long, unbranched; the stem is straight and grass-like, about 10-striate, subterete, slender, of a pale yellowish green colour, very nearly glabrous, except the uppermost part above the only pair of leaves extant on the specimen. Leaves more erect than spreading, nearly straight, minutely scabrid on the margin. Stipules none or fallen. Capitulum ovoid, $\frac{1}{2}$ in. long, not quite as much in thickness, bracteolate, mixed with white cottony wool; peduncle $\frac{1}{2}$ in. long, clothed with short white woolly hairs, bearing rather above the middle a pair of opposite ovate-acuminate caducous sessile 1-nerved bracts with green midrib and broad scarious margins, measuring $\frac{1}{6}$ in. in length. Flowers indefinite, crowded, sessile. Bracteoles ovate-lanceolate or linear, apiculate, cottony at the back, glabrous on the inner face, about as long as the flowers, with broad scarious margins. Perianth-segments $\frac{1}{6}-\frac{1}{5}$ in. long.

Serpa Pinto, no. 64.

SECOND SERIES.-BOTANY, VOL. II. 


\section{CYPERACE}

25. Kyllingia alba, Nees ab Es. in Linnæa, x. p. 140, n. 4 (1836); Boeck. in Linnæa, xxxv. p. 430, n. 28 (1868). K. cristata, Kunth, Enum. Cyperac. p. 136 (1837). Kyllingia sp., Burchell, 'Travels in the Interior of Southern Africa,' i. p. 538, note (1822).

This species occurs also in Extratropical South Africa, having been found by Ecklon, Zeyher, and Drège, in the eastern regions of Cape Colony, at an elevation of 3500 to 4000 feet, and in the southern part of the Kalahari region by Burchell, no. 1997, between Wittewater (or Gattekamma) and Aakaap (or Riet Fontein), on the morning of 15 February 1812. "Capitula alba."

Serpa Pinto, no. 65 .

26. Cyperds aureus, Humb. et Kunth (emend.), var. $\beta$. aurantiacus, Boeck. in Linnæa, XXxv. p. 495 , n. $64 \beta$ (1868).

This is a widely distributed tropical species. Our specimen is without leaves, but appears to belong here.

Serpa Pinto, no. 69.

27. Cyperus aristatus, Rottb. Gram. p. 23, t. 6. f. 1 (1773); Kunth, Enum. Cyperac. p. 23 (1837); Steud. Syn. Pl. Cyperac. p. 14, n. 132 (1855); Boeck. in Linnæa, xxxv. p. 500, n. 71 (1868).

This species occurs also in the East Indies, in both North and South America, in Senegambia, in Nileland, in Angola, in Damaraland, and in the Cape flora.

Serpa Pinto, no. 68.

28. Crperos, sp.

In our specimen, which is glabrous and without lower leaves, the stem is 6 inches long, smooth, striate, rather glossy and naked, at the apex with a pair of patent linear-subulate floral leaves 3-nerved and clasping at the base and rough-edged towards the apex, measuring respectively $\frac{1}{3}$ and $1 \frac{1}{4}$ in. ; the sessile spikelets are 6 in number, and measure from $\frac{1}{4}$ to $\frac{3}{5}$ in., oblong or lanceolate-oblong, radiating in a hemispherical manner, compressed, 2-edged, glossy, reddish-brown in the dry state, 13-33-flowered; the scales are rounded above with a short straight projecting apiculus, halfboat-shaped, with a small keel; the style is trifid, and the caryopsis ovoid, smooth, and very roundedly trigonous.

It appears to be an undescribed species nearly related to Cyperus amnicola, Kunth, Boeck. in Linnæa, xxxv. p. 509, n. 84, errore 83 (1868), and to C. rupestris, Kunth, Boeck., l. c. p. 510, n. 85, which are Cape and Natal species.

Serpa Pinto, no. 66.

29. Cyperts Margaritaceds, Vahl, Enum. Pl. ii. p. 307 (1806); Kunth, Enum. Cyperac. p. 46 (1837) ; Steud. Syn. Pl. Cyperac. p. 28, n. 294 (1855); Boeck. in Linnæa, xxxv. p. 529, n. 110 (1868). C. eburneus, Thonn. ex Boeck., l.c. p. 530. Cyperus 
sp., Burchell, Travels in the Interior of Southern Africa, vol. i. p. 538, note (1822).

This species has a wide distribution in Africa, occurring also in Upper Guinea, in the Transvaal, in the South-African Gold-fields, and in Damaraland, also in the southern part of the Kalabari region, as under :-

Burchell, no. 1992. "Parvus, spiculis albis." Between Klaarwater (or Kárrikamma) and Wittewater (or Gáttikamma), 14th February 1812.

Burchell, no. 2613. "Planta basi cæspitosa, basibus foliorum pseudo-bulbosa ; culmus setaceus, folia setacea excedens; spiculæ 2-4, lanceolatæ, albæ." Between Knegt's Fontein and Klip Fontein, on the morning of 26th December 1812. It was at this place and at this time that Burchell also collected Panicum nigropedatum, Munro, given in the enumeration below, page 29 .

Serpa Pinto, no. 61.

30. Cyperus rotundus, L. Fl. Zeylan. n. 36 (1747); L. Sp. Pl. edit. i. p. 45 (1753); Kunth, Enum. Cyperac. p. 58 (1837); Steud. Syn. Pl. Cyperac. p. 32, n. 351 (1855); Caruel, Prodr. Fl. Tosc. p. 670 (1864); Boeck. in Linnæa, xxxvi. p. 283, n. 213 (1869); var.?

Our specimen has extant none of the lower leaves of the plant; and its specific identification must remain uncertain. The species named is widely dispersed over most hot and warm countries; and numerous varicties occur. The type specimen in Hermann's Ceylon herbarium, part of the Banksian collection in the British Museum, has been compared; and in it the scales are more strongly ribbed than in our specimen.

Serpa Pinto, no. 67.

31. ScirPos Nindensis, sp. n. S. cæspitosus minute hirtellus bipollicaris vel tripollicaris, radicibus fibrosis capillaribus, culmis numerosis capillari-filiformibus rectis erectis vel suberectis valde inxqualibus nonnullis brevissimis angulari-sulcatis minute scabrido-hirtellis longioribus 2-3-pollicaribus folia longiora vix excedentibus basi foliatis, foliis inæqualibus longioribus capillari-filiformibus acutis canaliculatis dorso sulcatis carinatis minute hispidulo-hirtellis basim versus dilatato-vaginantibus margine membranaceis sparse ciliatis, vaginis brevibus fissis pallide fuscis, spiculis solitariis terminalibus anguste ovoideo-oblongis acutiusculis $\frac{1}{8}-\frac{1}{4}$-pollicaribus plurifloris, bracteis nullis vel squamas simulantibus, squamis imbricatis ovatis longe apiculatis erectis glabris vel puberulis demum glabris inferioribus longioribus dorso viridi-carinatis lateribus pallidis fuscescentibus, staminibus 3, caryopsi parva late obovoidea obtuse triquctra pallida vel subfusca transversim rugosula, angulis linea elevata lævi fusca notatis, apice tuberculo minimo persistente notata, stylo trifido exserto.

Nearly related to Scirpus sphcerocarpus, Boeck. in Linnæa, xxxvi. p. 741, n. 107 (1870), but differs by the 3-sided not globose fruit \&c.

Serpa Pinto, no. 63. 
32. Fimbristylis (§Oncostylis) Bdrchellit, sp. n. (Plate VI. B, figs. 7-15.) F. cæspitosa spithamæa vel ultra superne glabriuscula, radicibus fibrosis tenuibus, culmis pluribus gracilibus filiformibus infirmis erectis vel nutantibus angularibus sulcatis basi foliosis, foliis setaceo-filiformibus quam culmi sæpius bis vel ter brevioribus canaliculatis dorso subcarinatis basim versus fuscis dilatato-vaginantibus, vaginis brevibus ore pilis longis caducis vestitis, inflorescentia umbelliformi composita vel semicomposita pluriradiata $\frac{3}{4}-1 \frac{1}{2}$ poll. longa, radiis erecto-patentibus filiformi-capillaribus exterioribus longioribus, radiolis brevibus nonnullis brevissimis capillaribus erecto-patentibus, involucri foliolis imbricatis basi fuscis dilatato-amplexicaulibus laxe pilosulis infimo quam umbella bis breviore superioribus iterum brevioribus, spiculis ovali-oblongis leviter compressis 8 -14-floris $\frac{1}{8}-\frac{3}{8}$-pollicaribus, squamis adpressis aridis oblongo-ovalibus imbricatis obtusis vel breviter apiculatis dorso (in sicco) rubescenti-fuscis carina convergenter 3-nervi ad apicem squamæ evanescente vel excurrente margine scariosis, caryopsi minima late obovata obtuse triquetra pallida lævi, bulbo stylino minutissimo depresso fusco, stylo trifido tenui apice exserto.

This species occurs also in the southern part of the Kalahari region of South Africa, having been found by Burchell as under :-

Burchell, no. 2151, at the Klip Fontein (or Rock Fountain), in the country of the Kóras, on dry naked rocks, 19th June 1812. This number of Burchell's collection has been referred by Dr. Boeckeler, in Linnæa, xxxvii. p. 28 (1871), to Fimbristylis hispidula, Kunth, a species which belongs to the section Trichelostylis, and to which he ascribes a wide distribution over Africa. The specimens measure 8-16 inches in length, and the leaves $2 \frac{1}{2}-5$ inches. It was here and at this time that Burchell gathered Pellaca calomelanos, Link, given in the enumeration below, page 34 .

Burchell, nos. 2589, 2598, at the Kosi Fountain, 25th December 1812. These specimens measure about $7 \frac{1}{2}$ inches in length, and the leaves $4-5 \frac{1}{2}$ inches. It was at this station that Burchell at the same time obtained specimens of his Polygala krumanina; see page 16.

The species appears to be nearly related to Scirpus Schweinfurthianus, Boeck. in Linnæa, xxxvi. p. 758, n. 125 (1870).

The principal figure in Pl. VI. B, represents the natural size of one of Major Serpa Pinto's specimens; the detached spikelet is enlarged to about five diameters; and the dissections are more considerably enlarged.

Serpa Pinto, nos. 60, 62.

33. Fuirena Pubescens, Kunth, Enum. Cyperac. p. 182, n. 11 (1837); A. Rich. Tent. Fl. Abyss. ii. p. 497 (1851) ; Steud. Syn. Pl. Cyper. p. 126, n. 12 (1855); Boeck. in Linnæa, xxxvii. p. 104, n. 8 (1871); vel affinis.

The species quoted occurs in Portugal, Corsica, and other parts of the Mediterranean region, the East Indies, Nileland, and the Cape of Good Hope. Our specimen differs from the type by the more squarrose setæe of the spikelets.

Serpa Pinto, no. 70. 
34. Fuirena sp.? aff. $F$. pubescenti, Kth.

Our specimen is without lower leaves. The inflorescence is much denser than in the last; the spikelets are longer $\left(\frac{3}{8}-\frac{1}{2}\right.$ in.); and the setæ are long, firm, and straight. It appears to belong to an undescribed species.

Serpa Pinto, no. 71.

\section{GRAMINEA.}

35. Paspalum scrobiculatdm, L. Mant. i. p. 29 (1767); Kunth, Enum. Gram. i. p. 53, n. 89 (1833); Steud. Syn. Pl. Gram. p. 21, n. 74 (1855).

This species is widely dispersed over the tropical regions of the Old World, including Australia.

Serpa Pinto, no. 55.

36. Panicum chifare, Retz. Obs. iv. p. 16, n. 42 (1786); Kunth, Enum. Gram. i. p. 82 (1833); A. Rich. 'Lent. Fl. Abyss. ii. p. 360 (1851); Steud. Syn. Pl. Gram. p. 39, n. 20 (1855), cum syn.

Our specimen is without leaves, but agrees with this widely-spread species.

Serpa Pinto, no 44.

37. Panicum gosstrinum, A. Rich. Tent. Fl. Abyss. ii. p. 366 (1851), cum syn.; Steud. Syn. Pl. Gram. p. 56, n. 281 (1855).

Our specimen is without leaves, and must be compared with Panicum serratum, Br., a closely allied Cape species. Richard's species occurs also in Abyssinia and Natal, and in other parts of Extratropical South Africa. It has been found by Burchell in the southern part of the Kalahari region as under :-

Burchcll, no. 2186, at the Kruman station, June 30, 1812. Burchell, no. 2543, on the road from Little Klibbolikhonni and the (Great) Kosi Fountain, December 20, 1812 ; here Burchell also collected Indigefera heterotricha, DC., given in the enumeration above, page 18 .

Serpa Pinto, no. 46.

38. Panicdm nigropedatum, Munro, MS. in Herb. Kew.

The type of this species belongs to the southern part of the Kalahari region of South Africa; it was found by Burchell as under:-

Burchell, no. 2391, on the rocks at the Chue Spring, October 7, 1812.

Burchell, no. 2577, at the Kosi Fountain, December 24, 1812.

Burchell, no. 2610, between Knegts Fontein and Klip Fontein, December 26, 1812 : "stirps bipedalis, erecta, tota pubescenti-mollis ; folia ciliata ; spiculæ dense albido-hirtae; locustæ petiolus ater; folia velutina ut etiam bases radicales; perennis" (Burchell MS.). It was at this place and at this time that Burchell also collected Cyperus margaritaceus, Vahl, given in the enumeration above, page 26. This grass has also been collected by Baines in the South-African Gold-fields, 1870. 
Allied to Panicum serratum, Br., and P.gossypinum, A: Rich., but well distinguished; the black foot-stalks of the spiculæ are curious. (Monro, MS. in ПIerb. Kew.)

Serpa Pinto, no. 41.

39. Panicum maximum, Jacq. Ic. Pl. Rar. i. p. 2, t. 13 (1781); Steud. Syn. Pl. Gram. p. 72, n. 469 (1855); vel aff.

Our specimen is hirsute on the sheath of the uppermost leaf, is a less robust form; and the inflorescence is less umbellate than is usual in this species, which is widely spread over the tropics, and is said originally to have been native on the African continent; it also occurs at Natal.

Serpa Pinto, no. 43.

40. Panicum Insigne, Steud. Nomencl. Bot. edit. 2, pars ii. p. 258 (1841); Steud. Syn. Pl. Gram. p. 92, n. 747 (1855). Tricholena grandiflora, Hochst. in Herb. Schimp. Abyss. i. n. 205; A. Rich. Tent. Fl. Abyss. ii. p. 445 (1851).

This species occurs also in Abyssinia and South Africa.

Serpa Pinto, nos. 36, 50.

41. Aristida Barbicollis, Trin. et Rupr. Sp. Gram. Stip. p. 151 (1842); Steud. Syn. Pl. Gram. p. 141, n. 106 (1855). Chataria Forskolii, Nees ab Es. Fl. Afr. i. p. 188 (1841), excl. syn.

This species occurs also in castern districts of the Cape of Good Hope, in Natal, in the Transvaal, and in Zululand.

Serpa Pinto, no. 45.

42. Aristida vestita, Thunb. Prodr. i. p. 19 (1794); Kunth, Enum. Gram. i. p. 197, n. 74 (1833); Steud. Syn. Pl. Gram. p. 142, n. 113 (1855).

This species occurs also in other parts of South Africa.

Serpa Pinto, no. 49.

\section{Sporobolus leptostacirys, sp. $\mathrm{n}$.}

Our specimen is without leaves, but is suflicient for the determination of the genus, and differs from the described species of this genus. The specimen in the dry state is of a pale straw-colour throughout; the portion of the stem extant is terete, smooth, glabrate, shining, slightly wavy near the top below the spike, and measures, exclusive of the spike, $7 \frac{1}{2}$ in. The spike is very narrowly cylindrical, $4 \frac{1}{3}$ in. long, $\frac{1}{5}$ in. diam., terete, and without bracts at the base; the rhachis is marked with decurrent lines from the insertion of the spikelets. The spikelets are subsessile, narrow, more or less spreading, in many rows, $\frac{1}{10}$ in. long; pedicel very short, very shortly puberulous; glumes 1-nerved, about as long as the spikelet.

It is nearly related to Sporobolus spicatus, Kunth, Enum. Gram. i. p. 210, n. 1 (1833) (that is, to Vilfa spicata, Vahl), and appears on superficial examination to be identical, 
or nearly so, with a specimen in the Kew Herbarium from the Apies river, Transvaal, collected by Nelson, no. 102, partim.

Serpa Pinto, no. 58.

44. Schmidtia quinqueseta, Benth. MS. in Herb. Kew., vel affinis.

This species, which our species approaches, or perhaps belongs to, is illustrated by specimens which have been distributed from the Polytechnic School of Lisbon as part of the herbarium of Dr. A. R. Ferreira. It occurs also in Senegambia; in the Mozambique district, having been collected by Dr. J. Kirk at Shiramba, in dry plains, in January 1860 ; in the Transvaal, having been collected by Dr. W. G. Atherstone and by Mr. McLea in plains; in dar-Fur, at Gebel Sungur, distr. Surutj, having been collected by Dr. 'T. Pfund, no. 617, September 23, 1875 ; and in the southern part of the Kalahari region of Extratropical South Africa, having been collected by Burchell, no. 2361, in a walk from Giraffe Station to the First Camelopardalis, October 3, 1812. This species was referred in manuscript by Munro to a different genus. It differs from the original species of the genus, which belongs to the Cape-Verd Islands, by the more spreading and conspicuous setæ of the spikelets.

In our specimen, which is without foliage, the inflorescenec is less dense and less bighly compound, and the setæ, though conspicuous, yet are less spreading than in the types of $S$. quinqueseta. The genus was described by Steudel in J. A. Schmidt's 'Beiträge zur Flora der capverdischen Inseln,' pp. 144, 145 (1852), and consists, as at present known, only of the species mentioned above.

Serpà Pinto, no. 34.

45. Triraphis sp.?, vel affinis.

In our specimen the flowers are in very young bud, and there are no leaves; it, however, seems to be near or to belong to this genus, which is at present known to consist of 5 species from Australia (See 'Bentham and Mueller's Flora Australiensis,' vol. vii. pp. 603-605 (1878)), and of one species from the Caledon river, in Extratropical South Africa.

Serpa Pinto, no. 59.

46. Chloris Petrea, Thunb. Prodr. Pl. Cap. i. p. 20 (1794); Steud. Syn. Pl. Gram. p. 207, n. 59 (1855). Eustachys petraa, Desv. Journ. de Bot. 1813, i. 69; Kunth, Enum. Gram. i. p. 262 (1833), cum syn.

This species has a wide distribution, occurring also in the Cape districts, in the Orange Free State, in the West Indies, and in the southern states of North America. It is also given as an Abyssinian plant by Schweinfurth and Ascherson in Schweinfurth's 'Beitrag zur Flora Æthiopiens,' i. p. 298, n. 3505 (1867).

Serpa Pinto, no. 57.

47. Eragrostis gummiflda, Nees ab Esenb. Fl. Afr. Austr. i. p. 393 (1841); Steud. Syn. Pl. Gram. p. 271, n. 111 (1855); vel affinis. 
Our specimen is without leaves, but appears to belong to this species, which is known from the southern and eastern districts of the region of the Cape of Good Hope.

Serpa Pinto, no. 48.

48. Eragrostis Lappdla, Nees ab Esenb. Fl. Afr. Austr. i. p. 412 (1841); Steud. Syn. Pl. Gram. p. 272, n. 130 (1855).

This species occurs also in Natal and Zululand, whence the forms seen exhibit a denser inflorescence than our specimen; also with a lax inflorescence, as in our specimen, and as illustrated by a specimen collected in the southern part of the Kalahari region ly Burchell, no. 2199, between the river Makkwarin and Sikkloniani Fountain, July 10, 1812.

Serpa Pinto, no. 40.

49. Eragrostis obtusa, Munro, MS. in Herb. Kew. Briza geniculata, Thunb. Prodr. Pl. Cap. i. p. 21 (1794); Kunth, Enum. Gram. i. p. 372, n. 10 (1833); Steud. Syn. Pl. Gram. p. 282, n. 6 (1855).

This species occurs also at the Cape of Good Hope and in the Transvaal. Serpa Pinto, no. 47.

50. Eragrostis elata, Munro, MS. in Herb. Kew.

This species has been confused by authors with Eragrostis Urizoides, Nees ab Esenb. in Linnæa, vii. p. 328 (1832); it differs by its flatter and broader spikelets, with acute margins; it has a wide distribution, occurring also in Angola, Mozambique, at Delagoa Bay, in the Transvaal, Natal, Orange Free State, South-African Diamond-fields, and in the southern part of the Kalahari region.

Serpa Pinto, no. 32.

51. Eragrostis Nindensis, sp. n. E. subglabra nitida, culmis infra paniculam subteretibus nudis strictis minutissime scabridis intra paniculam angulosis apicem versus leviter flexuosis, panicula ad 5 poll. longa anguste pyramidato-oblonga racemosocomposita sublaxa apicem versus simplici ramis alternis in axillis pilosulis inferioribus $1-1 \frac{2}{3}$ poll. longis laxis superioribus gradatim brevioribus, spiculis linearioblongis compressis alternis $\frac{1}{2}-\frac{2}{3}$ poll. longis $\frac{1}{8}-\frac{1}{7}$ poll. latis $15-21$-floris patentibus breviter pedicellatis extremis erectis pedicellis longioribus suffultis, gluma floris late ovata obtusiuscula subapiculata rigide chartacea trinervia carinata glabra $\frac{1}{8}$ poll. longa, palea ovali obtusiuscula glabra bicarinata lateribus plicatis glumæ subrequilonga.

Our specimen is without leaves, but appears to be closely allied to Eragrostis chalcantha, Trin., and E. sclerantha, Nees ab Esenb., both of which are species occurring in southern and eastern districts of the Cape of Good Hope; it differs from both of them by longer spikelets and laxer inflorescence. It agrees, however, better with a specimen in the Kew Herbarium collected by Burke from the Caledon river, in the Orange Free State, which may belong to our species.

Serpa Pinto, no. 51. 
Another specimen, collected by Major Serpa Pinto, no. 35, differs from his no. 51 by a shorter, denser, and more highly compound inflorescence, with spikelets ranging up to $\frac{3}{4}$ in. long, bearing rather more numerous flowers (21-26) and more obtuse palea ; it may, however, belong to the same species, and, if so, would so far enlarge or modify the characters of the species given above.

52. Imperata arundinacea, Cyr. Pl. Rar. Regn. Neapol. fasc. ii. p. 27, t. 11 (1792); Kunth, Enum. Gram. i. p. 477 (1833), cum syn. ; Steud. Syn. Pl. Gram. p. 405, n. 1 (1855); Caruel, Prodr. Fl. Tosc. p. 695 (1864); Benth. et Muell. Fl. Austral. vii. p. 536 (1878).

This species is very widely spread over the warmer countries of the world, including Italy and Australia.

Serpa Pinto, no. 56.

53. Heteropogon hirtus, Pers. Syn. Pl. ii. p. 533 (1807); non Ands. ex Schweinf. et Aschers. in Schweinf. Beitr. Fl. Ethiop. i. p. 310 (1867). Andropogon contortum, L. Sp. Pl. edit. i. p. 1045, n. 1 (1753); Kunth, Enum. Gram. i. p. 486, n. 2 (1833); Steud. Syn. Pl. Gram. p. 367, n. 37 (1855); Benth. et Muell. Fl. Austral. vii. p. 517 (1878). Heteropogon contortus, Roem. et Sch. Syst. Veg. ii. p. 836 (1817).

This species extends over the warmer parts of both the Old and New Worlds, including Australia; but it does not occur in any part of Europe.

Serpa Pinto, no. 42.

54. Eliondrus argenteus, Nees ab Esenb. Fl. Afr. i. p. 95 (1841). Andropogon tenuifolius, Steud. Syn. PI. Gram. p. 365, n. 15 (1855).

The species occurs also in Extratropical South-eastern Africa. Our specimen is quite destitute of leaves; and we are not sure of the correctness of its identification.

Serpa Pinto, no. 37.

55. Andropogon insculptus, Hochst. in Herb. Schimp. Abyss. i. n. 80 ; A. Rich. Tent. Fl. Abyss. ii. 458 (1851); Steud. Syn. Pl. Gram. p. 380, n. 205 (1855).

Our specimen is without leaves, but appears to be identical with the above-mentioned species, which has previously been found in Abyssinia and Gallabat.

Serpa Pinto, no. 54.

56. Andropogon anteistirioides, Hochst. in Пlerb. Schimp. Abyss. iii. nn. 1822, 1832 ; A. Rich. Tent. Fl. Abyss. ii. p. 463 (1851); Steud. Syn. Pl. Gram. p. 386. n. 283 (1855).

The species occurs also in Abyssinia, and is probably a variety of Andropogon cymbarius (L.), a species which extends from the East Indies to Nileland and South Africa. Our specimen is without lower leaves.

Serpa Pinto, no. 53. 
57. Andropogon Schcenanthus, L. Sp. Pl. edit. i. p. 1046, n. 6 (1753); Kunth, Enum. Gram. i. p. 493, n. 51 (1833); Steud. Syn. Pl. Gram. p. 387, n. 296 (1855); Benth. et Muell. Fl. Austral. vii. p. 534 (1878).

This species, with its varieties, is widely spread over the hotter parts of the Old World, and extends to Australia. The type specimen in the Linnean herbarium has been inspected for comparison.

Serpa Pinto, no. 33.

58. Andropogon eucomus, Nees ab Es. Fl. Afr. Austr. i. p. 104 (1841); Steud. Syn. Pl. Gram. p. 390, n. 331 (1855); Grant et Oliv. in Trans. Linn. Soc. Lond. xxix. p. 176 (1875). Eriopodium Kraussii, Hochst. ex Krauss in Flora, Jahrg. 29, 1846, p. 115, et Beitr. Fl. Cap- und Natall. p. 186 (1846).

This species occurs also in Lower Guinea, the upper part of Nileland, the Mozam. bique district, Natal, and the south-western districts of the Cape of Good Hope.

Serpa Pinto, no. 39.

59. Andropogon punctatus, Roxb. Fl. Ind. ed. Carey, i. p. 268 (1820); Kunth, Enum. Gram. i. p. 506, n. 137 (1833); Steud. Syn. Pl. Gram. p. 391, n. 343 (1855).

This species occurs also in other parts of Africa and in India.

Serpa Pinto, no. 52.

FILICES.

60. Pellea calomelanos, Link, Fil. Hort. Berol. p. 61 (1841); Hook. Bot. Mag. t. 4769 (1854); Hook. Sp. Fil. ii. p. 140 (1858), cum syn.; Hook. et Baker, Syn. Fil. p. 152 (1868).

This species occurs also in the Cape flora at an elevation of 400-4000 feet in rocky situations, in the Transvaal and Natal, in the Mozambique district and Lower Guinea, also in the island of Bourbon, and at an elevation of 4000-6000 feet among the Himalaya mountains ; it is also reported from Abyssinia.

Burchell found this fern in the southern part the Kalahari region, in the same locality as our Fimoristylis Burchellii, described above, page 28.

Serpa Pinto, no. 72. 


\section{DESCRIPTION OF THE PLATES.}

\section{Plate III.}

\section{A. Figures 1 \& 2. Dianthus Serpa, Ficalho et Hiern.}

Fig. 1. The whole specimen, folded in two places, natural size.

2. The flower dissected, the calyx and four of the petals having been removed, enlarged to two diameters.

\section{B. Figures 3-12. Indigofera splendens, Ficalho et Hiern.}

Fig. 3. A flowering branch, natural size.

4. A portion of a leaf, bearing a pair of leaflets, enlarged to two diameters.

5. A detached flower, enlarged to two diameters.

6. The standard detached from the flower, enlarged to about two diameters.

7. A wing-petal detached, enlarged to rather more than two diameters.

8. The keel detached, enlarged to rather more than two diameters.

9. The flower after the removal of the petals, showing the andrœcium, enlarged to four diameters.

10. An anther with a piece of its filament, enlarged to about eight diameters.

11. The pistil detached, enlarged to about four diameters.

12. A young legume, enlarged to about two diameters.

\section{Plate IV. Amphidoxa filaginea, Ficalho et Hiern.}

Fig. 1. The whole specimen, natural size.

2. A frustum of a branch, bearing two leaves, enlarged to six diameters.

3. A detached capitulum, cularged to five diameters.

4. One of the inner bracts of the involucre detached, as seen from the inner side, enlarged to nearly thirty diameters.

5. A female floret, enlarged to thirty diameters.

6. The upper part of the style of a female floret, enlarged to about fifty diameters.

7. A hermaphrodite floret, enlarged to about thirty diameters.

8. Part of the andrœcium of a hermaphrodite floret, enlarged to about fifty diameters.

9. The style of a hermaphrodite floret, enlarged to about thirty diameters.

10. One of the setæ of the pappus of a hermaphrodite floret, enlarged to about forty diameters.

\section{Plate V. \\ Diplorhynchus psilopus, Welw.}

Fig. 1. A flowering branch, natural size.

2. A detached flower, enlarged to four diameters.

3. The same before expansion, enlarged to four diameters.

4. The interior of a flower laid open, enlarged to about five diameters.

5. Front view of a stamen, enlarged to about twelve diameters.

6. Side view of a stamen, enlarged to about twelve diameters.

7. The flower after the removal of the corolla, enlarged to about eight diameters.

8. The pistil, enlarged to nearly twelve diameters.

9. The ovary cut transversely, showing the ovules in position, enlarged to about twelve diameters. 
Plate Vi.

A. Figures 1-6. Crabbea ovalifolia, Ficalho et Hiern.

Fig. 1. The whole specimen, natural size.

2. A detached flower, with a subtending bract, enlarged to about two diameters.

3. The interior of a flower laid open, enlarged to about three diameters.

4. Nearly front view of one of the stamens, enlarged to about eight dimeters.

5. Nearly side view of one of the stamens, enlarged to about eight diameters.

6. The pistil, enlarged to nearly six diameters.

B. Figures 7-15. Fimbristylis Burchellii, Ficalho et Hiern.

7. A specimen of the whole plant, natural size.

8. The upper portion of a leaf, enlarged to about ten diameters.

9. A spikelet detached, enlarged to about five diameters.

10. A flower detached from the spikelet, with its scale, enlarged to about twenty diameters.

11. The back view of a scale, enlarged to about twenty diameters.

12. A detached flower, enlarged to about thirty diameters.

13. A fruit, enlarged to about thirty diameters.

14. The same, cut across the middle, enlarged to about thirty diameters.

15. A seed, enlarged to about thirty diameters. 
Trang Linn Soc Ser 2. Bor Vos. Il. Pl.3.
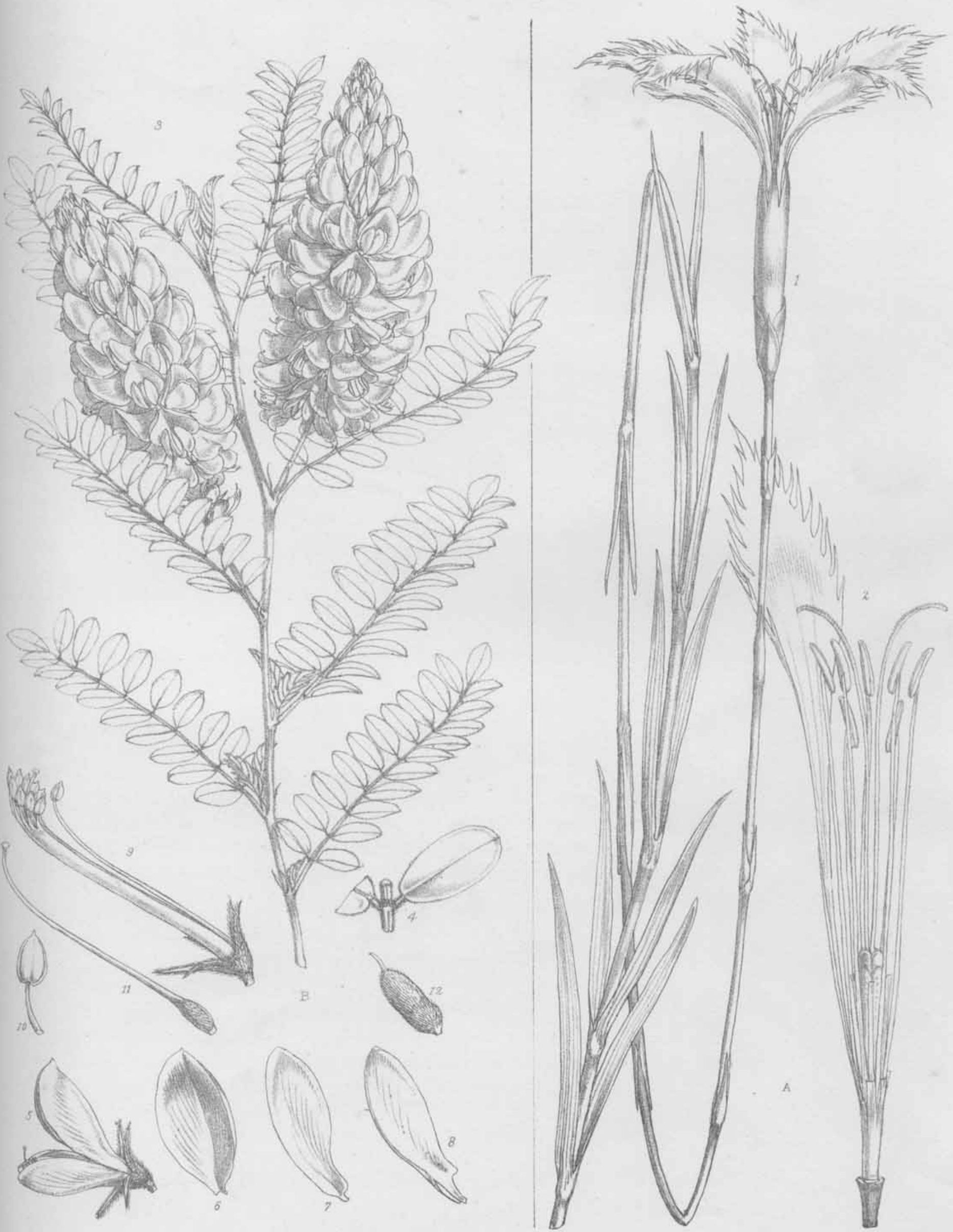

wHFteh del et hth 


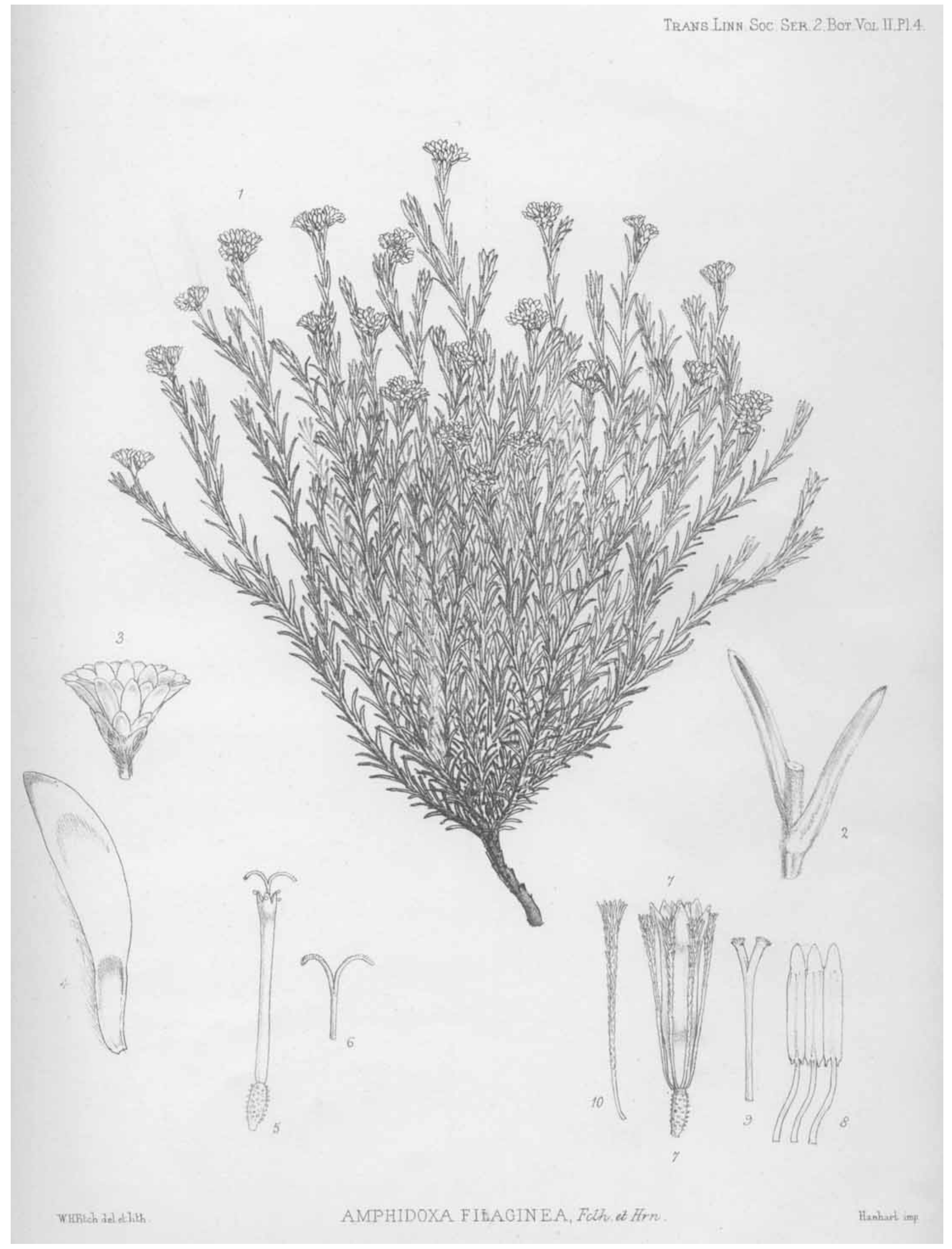




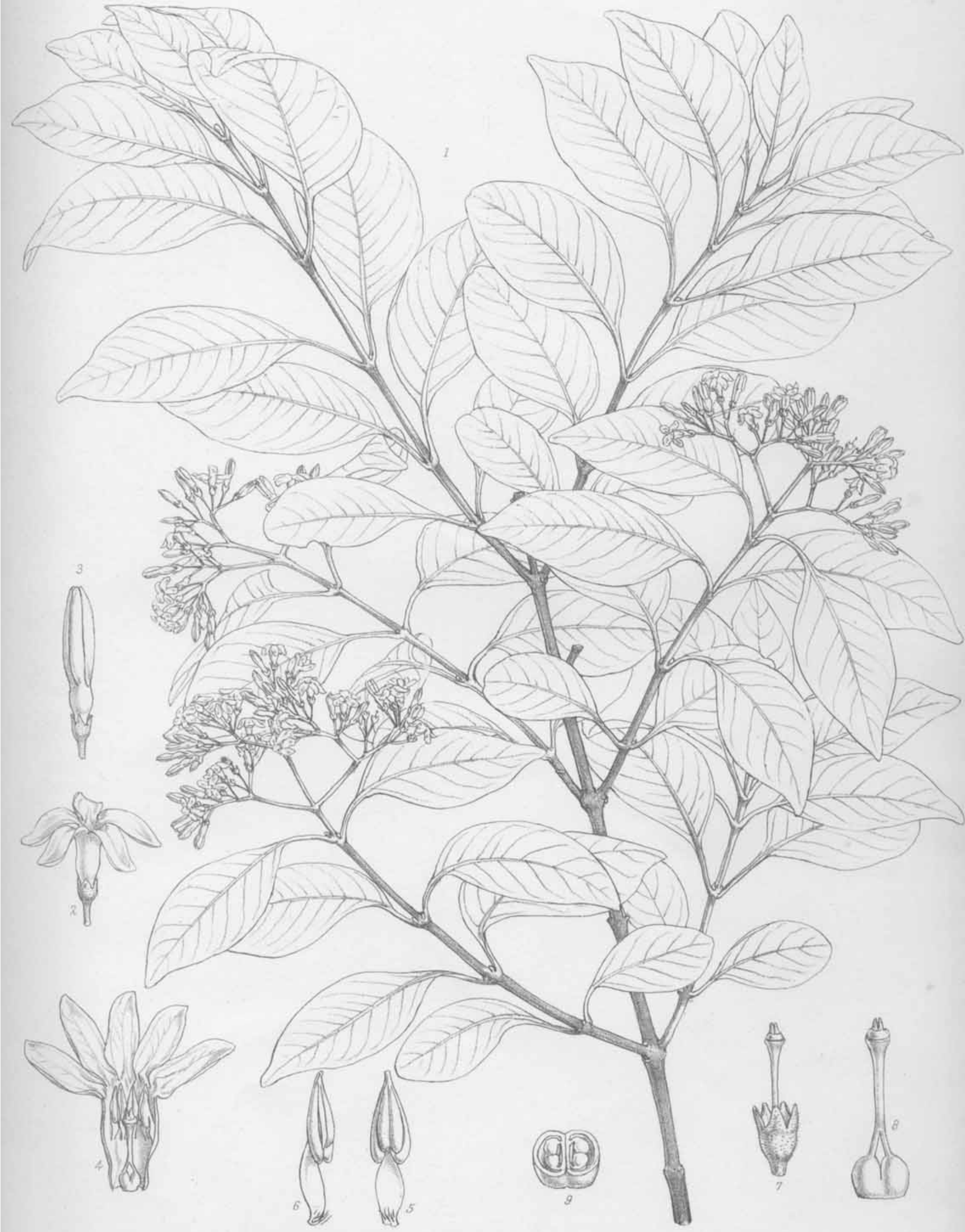




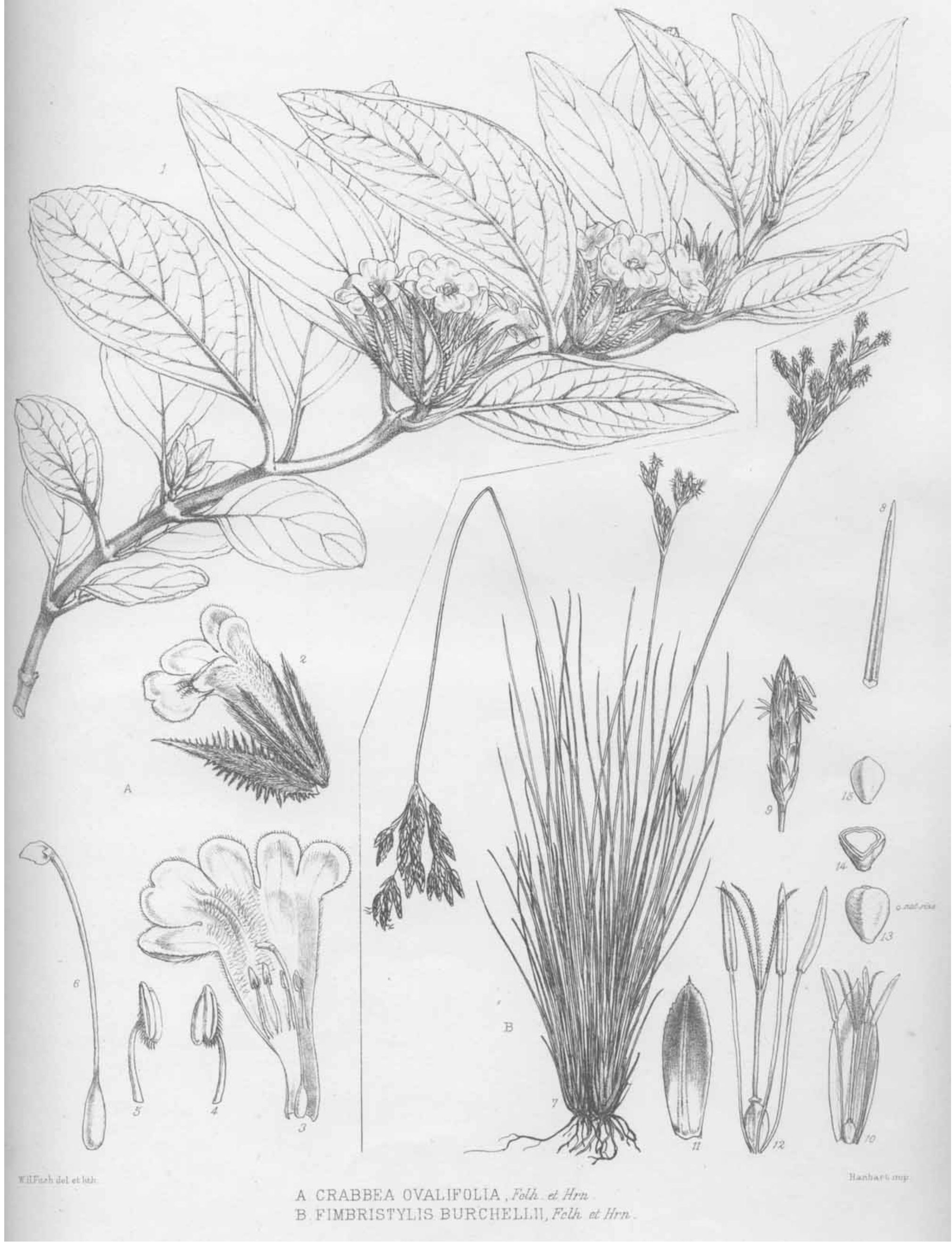

